\title{
The image of the teacher held by learners from 10 different countries: A new perspective on the causes of problems with learner discipline
}

\begin{abstract}
Authors:
Charl C. Wolhuter ${ }^{1}$

Johannes L. van der Walt ${ }^{1}$

Ferdinand J. Potgieter ${ }^{1}$

Affiliations:

${ }^{1}$ Research Focus Area: Unit for Education and Human Rights in Diversity, Faculty of Education Sciences, Potchefstroom Campus, North-West University,

South Africa
\end{abstract}

\section{Correspondence to: Charl Wolhuter}

Email:

charl.wolhuter@nwu.ac.za

Postal address:

Private Bag X6001,

Potchefstroom 2520,

South Africa

Dates:

Received: 07 Jan. 2013

Accepted: 11 June 2013

Published: 11 Nov. 2013

How to cite this article: Wolhuter, C.C., Van der Walt, J.L. \& Potgieter, F.L., 2013, 'The image of the teacher held by learners from 10 different countries: A new perspective on the causes of problems with learner discipline', Koers - Bulletin for Christian Scholarship 78(3), Art. \#554, 11 pages. http://dx.doi.org/10.4102/ koers.v78i3.554

\section{Copyright:}

(C) 2013. The Authors. Licensee: AOSIS OpenJournals. This work is licensed under the Creative Commons Attribution License.

Read online:
The article reports on research that investigated the image of teachers held by school learners. Based on a conceptual-theoretical distinction between the ideal teacher, the totally effective teacher and the typically excellent teacher, it was assumed that learners would focus on the first, which is a mental construct, and not on the third, which refers to a flesh-and-blood person actually found working in classrooms. They would not be aware of the discrepancy existing between the ideal teacher and the actual typically excellent teacher. A hundred learners in each of England, Latvia, Greece, Serbia, Slovenia, Bulgaria, Turkey, Pakistan, South Africa and Mexico were asked to write a one-page essay on the following topic: 'What does a typical teacher look like?' The investigation confirmed the correctness of the assumption. Despite clear instructions to describe a typical teacher, many respondents from all 10 countries described what they regarded as the ideal teacher. There seems to be a discrepancy between what learners want in a teacher (the ideal teacher) and what they actually have (the typical teacher). It is also possible that the lack of exposure to truly transformative teachers may in many instances lead to ineffective education. This may be one of the causes of problems with learner discipline in school that has thus far been overlooked in the scholarly pursuit to get to the root of problems with learner discipline, possibly because it does not fit neatly into the widely used model of categorising the causes of problems with learner discipline in schools.

Die beeld van die onderwyser volgens leerders van 10 verskillende lande: 'n Nuwe perspektief op die oorsake van leerderdissiplineprobleme. Hierdie artikel berig oor navorsing waarin die beeld wat skoolleerders van onderwysers huldig, ondersoek is. Gebaseer op 'n konseptueelteoretiese onderskeid tussen die ideale onderwyser, die volledig-effektiewe onderwyser en die tipiese onderwyser is daar van die veronderstelling uitgegaan dat leerders op die eerste, wat ' $n$ teoretiese konstruk is, sou fokus en nie die een wat' $n$ werklike persoon van vlees-en-bloed voor in 'n klaskamer vol leerders voorstel nie. Hulle sou nie bewus wees van die gaping tussen die ideale onderwyser en die werklike tipiese, uitstekende onderwyser nie. 'n Groep van 100 leerders uit Engeland, Litoue, Griekeland, Serwië, Slowenië, Bulgarye, Turkye, Pakistan, Suid-Afrika en Mexiko is versoek om 'n enkelbladsy-opstel oor die tema: 'Hoe lyk die tipiese onderwyser?' te skryf. Die ondersoek het die veronderstelling bevestig. Ten spyte van duidelike aanwysings om die tipiese onderwyser te beskryf, het al die respondente die ideale onderwyser beskryf. Dit blyk dat ' $n$ teenstrydigheid bestaan tussen die beeld van ' $n$ ideale onderwyser en die werklikheid voor die leerders in die klaskamer. Die moontlikheid bestaan dat die gebrek aan blootstelling aan waarlik transformerende onderwysers tot oneffektiewe onderwys kan lei. Indien wel, kan dit een van die oorsake vir skole se leerderdissiplineprobleme wees - 'n faktor wat tot nou in wetenskaplike pogings om tot die wortel daarvan deur te dring, oor die hoof gesien is, waarskynlik omdat hierdie faktor nie gemaklik in die algemeen gebruikte model van leerderdissiplineprobleme op skool inpas nie.

\section{Introduction: An overlooked cause of learner problems in schools}

Learner discipline constitutes a problem in South African schools, as is abundantly clear from scholarly publications (cf. Eloff, Oosthuizen \& Steyn 2010) and media reports alike (Cilliers 2009:4). By all accounts, this problem with learner discipline is not unique to South Africa but occurs on all continents (cf. Russo \& Wolhuter in press). Over the past decade, a host of publications in scientific journals have appeared on the topic in South Africa, commencing with the special edition of Koers - Bulletin for Christian Scholarship 68(4) in 2003. Although publications such as Heystek (2010), Wolhuter and Van Staden (2009) and Van der Westhuizen, Oosthuizen and Wolhuter (2008) investigated various possible causes of problems with learner discipline, they 
invariably took as their model the taxonomy of causes as enunciated in the monumental report of learners' discipline problems in schools in England (Department of Education and Science and the Welsh Office [DESWO] 1989). This report distinguishes between five sets of causal factors behind problems with learner discipline at school, namely learnerrelated factors, teacher-related factors, school-related factors, parent-related factors and society-related factors (DESWO 1989). Learner-related factors are understood as factors such as the age and gender of the learner, and teacher-related factors as those that include the experience of the teacher and the quality of the training of the teacher (DESWO 1989). Using this model as theoretical framework, these different factors have all been researched in the South African context over the past 10 years. This research includes:

- learner-related factors (Wolhuter, Oosthuizen \& Van Staden 2010)

- parent-related factors (De Wet 2010)

- teacher-related factors (Heystek 2010)

- school-related factors (Van der Westhuizen et al. 2008)

- society-related factors (Van der Walt, Potgieter \& Wolhuter 2009).

One cause of problems with learner discipline that does not seem to have been captured in this otherwise workable conceptualisation of its causes is the image that the learner has of the teacher. Learners' image of teachers seems to have evaded the attention of researchers because it does not seem to fit neatly into either the commonly referred to teacherrelated or learner-related factors. This article suggests that the image of the teacher that is held by the learner is also an important factor as far as the incidence of problems with learner discipline in schools is concerned. If learners look up to the teacher as a role model, that is, if they voluntarily make themselves disciples of the teacher, and the teacher endeavours to be a paragon of an integrated, whole, noble and disciplined person, discipline problems are likely to be absent or, at best, minimally present. The authors have been involved over the past 2 years in a research project that generated a database on the basis of which it was possible to investigate the possible causes of problems with learner discipline, not only in South Africa but also internationally.

\section{Problem statement}

Based on the conceptual-theoretical framework outlined in the next section, it was assumed that learners, when asked to write about what they regarded as a typically good or effective teacher, would respond by writing about what they felt would be an ideal teacher. Put differently, it was expected that they would not write about actual flesh-and-blood teachers but rather about a Platonic ideal-typical or a Kantian noumenon-type of teacher. The purpose of the research was to test this assumption. Put differently, the research wanted to establish the existence, or not, of a discrepancy between the image of the teacher learners wish for and the teachers they actually have. It is our contention that the lack of discipline experienced in some schools and classrooms could be attributed to the existence of such a discrepancy. Why and how this might be the case will be argued in the discussion of the conceptual-theoretical framework of the empirical investigation that was done.

\section{Conceptual-theoretical framework Theorising learner discipline}

As far as classroom discipline is concerned, the noun 'discipline' is usually understood predominantly in functionalist terms as a form of regulation or control - to create and maintain order (Millei, Griffiths \& Parkes 2010:13). Power associated with ideas of regulation and control in this context is thought about in structuralist terms, which is possessed (by the teachers) and represents a powerful will over the powerless (the learners). This creates a problem that revolves around the opposing ideas of learners' freedom, or autonomy, and teachers' dominance, or control. As such, it constructs an axis between maximum freedom and maximum control according to the personal power that the teachers exert and the personal power that the learners have. In this way, laissez-faire approaches to learner discipline are located on the maximum-freedom end whilst autocratic approaches are located on the opposite end. Other approaches are also lined up on this axis according to the level of freedom they allow for students as well as the teacher control that they carry (ibid:13). Given the current resilient entrenchment of the prospects of democracy, social justice and human rights, approaches to discipline that endow learners with autonomy and freedom are currently preferred and advocated by most scholars in the field (ibid:13).

Arguing from the late-modernist notion of learners' rational autonomy, most theorists promote the opinion that selfregulation (i.e. the ability and determination to regulate one's life by rules that one has accepted freely for oneself) represents the most desirable key to learners' freedom. The problem with this opinion is that any form of disciplinary control initiated by the classroom teacher that is essentially external to the learner is logically and morally undesirable, negative and even oppressive (Millei et al. 2010:85). Some scholars also argue that any form of learner discipline that is externally applied is not only a form of control and dominance that aims to subject the learners to the will of the designated authority (i.e. the teacher and, by proxy, the school and its governing body) but that it also actually impedes the learning process, instead of promoting and enhancing it (ibid:14). All this begs the question: 'What does the image that learners have of the 'typical teacher' - who is usually also responsible for dispensing external forms of learner discipline in the classroom - look like?'

\section{Ideal, good, effective and typical teachers}

Good teachers have been studied ever since Plato described how Socrates taught by asking his audience questions (Beishuizen et al. 2001:185). Since the 1920s, many researchers have, however, started to conduct empirical studies that explored the qualities and characteristics of, for example, the 'ideal teacher', the 'totally effective teacher' and the 'typically excellent teacher' (Liu \& Meng 2009:313). The frustrating reality is that, even to this day, there is no single factor 
that defines nor consensus in the literature about what makes an 'ideal teacher' or a 'totally effective teacher' or a 'typically excellent teacher'. For purposes of this project, we decided to distinguish between the three images of teachers, mentioned above.

Many decades of philosophical theory and empirical research have explored factors such as pedagogies used by teachers (Liu \& Meng 2009:313), the effects of teachers' backgrounds (e.g. degrees, experiences, socio-economic status, etc.; Pinto et al. 2012:74), and teachers' personal characteristics and behaviour (e.g. empathy, communication skills, etc.; Beishuizen et al. 2001:185; Cothran \& Hodges Kulinna 2006:178). In 2004, however, scholars were enabled to start studying the abovementioned factors more methodically by Moore's identification of three dominant scholarly discourses on the notion of the good teacher, namely:

1. charismatic subject

2. competent craftsperson

3. reflective practitioner. (Moore 2004)

These three discourses are not mutually exclusive. They usually operate in conjunction with one another (Pinto et al. 2012:80-85), as the discussion that follows will endeavour to illustrate.

The image of the 'ideal teacher' is a mental construct in the mould of the Platonic ideal-type or the Kantian noumenontype that does not in any way relate to a real flesh-and-blood person actually teaching in a school. When we apply Moore's three-discourse theory to the notion of the 'ideal teacher', it seems that this mental construct typically endeavours to visualise the teacher as the ideal embodiment of a perfect intrinsic balance between certain charismatic dispositions, teaching-related skills and competencies and reflective abilities. This does not, however, imply that some actual reallife teachers might not possess one or more of the behaviours and characteristics attributed to the ideal teacher. However, the likelihood of all these features, characteristics and behaviours converging in a single practising teacher is rather slim. No actual teachers will or can, for instance:

- Always be punctual.

- Maintain cordial and pedagogically sound relationships with the students.

- Be complete masters of their subject.

- Be meticulously prepared for every lesson and every contingency.

- Be fully effective as teachers, both in the pedagogical sense of guiding and equipping the learners to full and responsible maturity and in terms of examination results, namely straight A's from all the students (cf. Liu \& Meng 2009).

- Maintain excellent discipline without any sign of unrest, disorder, disturbance or any wayward behaviour in the classroom.

- Constantly apply effective and pedagogically justifiable disciplinary measures to learners in the classroom.

- Continuously reflect effectively, accurately and metacognitively about their own teaching theory and practice.
- Always be enthusiastic about their profession.

- Persistently not find themselves in conflict with either their learners or their colleagues.

- Regularly manage their personal mental state (worry about their learners or family, illness or unfortunate events, for instance) so that it does not interfere with their professional work.

- Unerringly devote all their time to their students' needs, both in class and extramurally.

The list of ideal behaviours and attributes can be endless. Nevertheless, it is clear that such a person does not, and cannot, exist in real life.

The second teacher image, to which we referred as the 'totally effective teacher', can to some extent be found in the flesh and actually working in a classroom. According to empirical research by Fraenkel (cited in Dyer 2002), the effective teacher is characterised by attributes and behaviours such as:

1. having high expectations of students

2. stressing depth of learning rather than coverage

3. explaining things clearly to the students

4. being a good listener

5. demonstrating patience with the students

6. varying the kinds of activities in which the learners are engaged in class

7. possessing an incredible amount of energy

8. displaying considerable demand of the subject matter and being able to relate to a variety of daily life examples

9. ensuring that the learners do, in fact, learn. (p. 9)

Dyer's (2002:8-9) research confirmed all of these attributes, with the exception of the first. In view of the above, it seems reasonable to assume that the totally effective teacher will also be able to maintain discipline effectively in the classroom.

Whilst it is possible to find a teacher who is fully effective in all these respects, it can be assumed that this is, again, highly unlikely. Moore's (2004) work suggests that the notion of the 'totally effective teacher' may indeed also reflect an unrealisable image of the teacher as one who is able to balance charismatic dispositions harmoniously and continuously with teaching-related skills and competencies as well as with concomitant reflective abilities.

Not many teachers succeed in being able to excel in respect of all these attributes. For this reason, we resorted to a third image, to which we referred as the 'typically excellent teacher'. This image is that of a real flesh-and-blood person standing in front of a class, a person who occasionally demonstrates all the iniquities so typical of human beings, either because of stressful situations (such as the school or home setting often might become) or because of relationship problems (with students, colleagues, at home and in other environments). The following are human characteristics of typically excellent teachers:

1. They might occasionally experience difficulties with the application of discipline in the classroom.

2. Their learners might at times be unruly and rude.

3. They might become angry at the perpetrations of the learners. 
4. They might lapse into a laissez-faire mood where they may allow the learners do what they want, seemingly without caring.

Moore's (2004) work furthermore suggests that the 'typically excellent teacher' is one who mainly demonstrates particular charismatic attributes and who is able to combine these with teaching-related skills and competencies. It would, however, seem that even the typically excellent teacher usually demonstrates little or no reflective competence (Beishuizen et al. 2001:185; Liu \& Meng 2009:313; Pinto et al. 2012:85). On the whole, the typically excellent teacher will have mastered the art of maintaining good order and discipline in the classroom as a prerequisite for good interaction with the learners as well as for effective teaching.

As intimated, the typically excellent teacher is the person who can occasionally demonstrate an ability to be highly effective in terms of the attributes mentioned above, though not constantly and not consistently. These teachers may demonstrate brilliance in a few of these attributes but may fail in others, occasionally even dismally. In the opinion of the learners and their parents, their colleagues and others, they are nevertheless excellent teachers - people who occasionally self-reflect about their capabilities (Korthagen \& Vasalos 2005:68) and are hence able to maintain a healthy balance between the various aspects and facets of their professional work as an educator. They are people who are aware of the emotional side of their learners and others. They are people who are non-threatening but rather inviting, who are capable of developing the self-directed capacity of their students and who can stimulate curiosity, commitment (e.g. to learning) and self-confidence. In Nussbaum's (2000:5) words, they are able to develop the human capabilities of their students, that is, they are able to help them to do and become what they are actually able to do and to be. They are able to treat every student as an end and not as a mere tool of others. According to Robeyns (2005:94), focus on the development of students' individual capabilities will lead to their individual wellbeing since it focuses on 'what people are effectively able to do and to be'.

\section{The transformative teacher}

In 2012, Pinto et al. (2012:74) identified a fourth conception of good teaching, namely the transformative teacher. This fourth discursive frame, whilst not part of Moore's (2004) original framework, is one that is prominent in the literature, particularly the body of work concerned with social justice and educational leadership (Van Deventer 2010). In transformative models of education, teachers and learners examine their own frames of reference and those of others by critically reflecting on underlying assumptions and beliefs that are taken for granted (Pinto et al. 2012:76). At the heart of transformative teaching is Paulo Freire's (2007) belief that education ought to empower learners to recognise connections between their individual problems and experiences, the social contexts in which they are embedded and broader ruling relations in society. The transformative teacher uses the academic subject matter and pedagogic content as a virtual 'magician's backdrop' against which reality may be 'unveiled'. In this way, transformative teachers allow learners to gain liberating insight into how the oppression they experience is socially generated. The aim of this insight is to break the 'culture of silence' as well help students explore how they can become agents in creating a just society.

The notion of the transformative teacher furthermore seems to reflect, amongst others, a spiritual quality: a sincere respect and appreciation for and embracement of a sacred dimension in the life-world of both the teacher and the learners. It speaks to their understanding of their being-inthe world (Engebretson 2003:9). It is the conduit through which a transcendental, ultimate reality impacts on the teacher and the learners alike, transforming them so that they increasingly would tend to live their lives in service of these ultimate realities (Hardjono \& Klamer 2005:21). It is essentially an energetically motivated, focused, conscious, purposeful and passionate quest - a condition known by a feeling of being wholly captured. According to De Muynck (2008), it is:

... the manner in which one - by orienting [sic] oneself on sources - relates beliefs and experiences of inspiration and/or transcendence, more or less methodically, to the actual practice of life. (p. 7)

Because of the concern with active learner involvement towards transformation, a transformative teacher is aware of social justice and fosters critical inquiry in the classroom and within the school environment. In this way, the teacher and the learners develop knowledge, skills, values, dispositions and actions that are called for by a reconstructive conception of democracy (Pinto et al. 2012:76).

This brings us to the 'discrepancy theory' that we mentioned in the problem statement above. As mentioned, we assumed that learners, when requested to write about the typical good teacher, would rather write about the ideal-typical teacher and not realistically about a flesh-and-blood person that they would expect to find in their classroom. We furthermore assumed that they might not necessarily recognise the pedagogically transformative possibility of a teacher's spirituality. We contended that this discrepancy, if it indeed existed, could explain a number of phenomena that teachers nowadays have to deal with, including discipline problems and the failure on the part of teachers to be 'good' or 'effective' in terms of being agents of transformation.

Transformative teachers can be lead into a minefield of disciplinary problems by their ideals to empower learners to recognise connections between their problems and experiences, the social contexts in which their problems are embedded and the use of the academic subject matter and pedagogic content knowledge to 'unveil' reality (thus allowing the learners to gain liberating insight into the oppression that they experience and how they can become agents in creating a just society). How do transformative teachers teach learners, for instance, to be critical of the forces that govern their lives? How do they teach them to become agents of change 
who might even attempt to overthrow such forces without negatively affecting their own authority in a classroom and without disrupting efforts at maintaining good order and discipline in the classroom? How can learners be inspired to act on transformative advice without the teachers themselves becoming the unwilling victims of what they preach?

\section{Life-conceptual perspective}

All of what has just been said about the role of the typically effective teacher can of course be interpreted in various ways, depending on the worldview one takes. From a Christian viewpoint, for instance, the idea that young people are developed to do and be what they are supposed to do and be can be reinterpreted as guiding, equipping, leading and enabling them to be able to perform according to the creation mandate. Furthermore, the aim can be to have them well prepared for their life calling of loving themselves, their neighbour and, above all, the triune God of the Bible. It could be seen as preparation for their calling to execute loving and caring stewardship over the entire creation to the glory of God. Of particular importance in the context of the investigation, to be reported on in the next section, are notions of discipling, discipline and disciplining as matters that the typically effective teacher will (and should - normatively) attend to. These terms all derive from the Latin discipulus [follower] from discere [to learn]. The closely related term disciplina [teaching, instruction, knowledge] is reflected in modern English as 'discipline' - a scholarly subject to be mastered.

According to Cloud and Townsend (1992:179), educators (in this case, typically effective teachers) should aspire to the inculcation of two forms of discipline in their learners. The first can be termed 'external discipline', which can be observed in terms of the order and system prevalent in, for instance, a classroom. This outward form of discipline is only instrumental in inculcating the second form of discipline, namely of enabling, guiding and equipping the learners to develop a set of internal boundaries, structures and responsibility. Discipline has two sides, a positive and a negative. On the positive side, one finds proactivity, prevention and active instruction. The purpose of these interventions is to keep the learners constructively and creatively busy so that they do not stray into socially unacceptable patterns of behaviour. Positive discipline is in line with the injunction of the Bible to raise children in the training and instruction of the Lord (Eph 6:4). The negative side of discipline is correction, chastisement and consequences, that is, letting children suffer the results of their actions (Pr 15:10). Good child-rearing, Cloud and Townsend (1992:179) conclude, involves preventive training, practice and correctional consequences. The price of punishment and chastisement is too high (Rm 6:23; Ja 2:10). Discipline is different, however. It is not payment for a wrong that was done. It is the natural Law of God, Cloud and Townsend (1992:180) aver; it is the reaping of the consequences of our actions.

Collins (2009:609-611) stresses the normative nature of this unstated higher standard, the Moral Law of God, by referring to it as the law of right behaviour. This is a law applicable only to human beings: the awareness of right and wrong, along with the development of language, awareness of self and the ability to imagine the future. Whilst the ability to distinguish right from wrong appears to be universal amongst all members of the species (though its application may result in widely different outcomes), what is right is ignored regularity, thus leading to the reaping of the consequences of actions and to other forms of punishment.

What the typical effective teacher should bring home to the learners is to debate within the self whether one action or another is a closer approximation to the demands of the Moral Law of God, as interpreted from the teacher's own particular worldview. Whilst the Moral Law is universal as a God-given law for all people, its interpretation and practical application are particularistic in terms of worldview. A typically effective teacher's application of the Law, that is, from a biblical perspective, will differ from the applications of others who work from the vantage points of different worldviews. A typically effective Christian teacher will be aware - as will all other typically effective teachers - of the importance of pedagogical principles such as respect for learners and allowing them the freedom (of will) to make responsible choices. Such teachers will also be aware of reciprocity and the role of values (Van Crombrugge 2006:85ff.), but they will interpret all of these pedagogical values from a pertinently biblical perspective as opposed to a secular humanist or a Buddhist perspective, to mention only two examples.

The secular humanist Dennett (2003:271) also feels the need to distinguish between those who are morally responsible and those who 'are excused because they don't make the grade'. He then goes on to make the distinction on rational, scientific grounds as well as on a person's own ability to become a responsible moral agent. The ability to create oneself as a responsible moral agent will depend on luck, environmental scaffolding and gradualism. Dennet (2003) claims:

With a little bit of luck, and a little help from your friends, you put your considerable native talent to work, and bootstrap [...] your way to moral agency, inch by inch. (p. 272)

Buddhists also reach for such moral agency in the human being by seeking to find the divine in themselves. This is done by following the Middle Way, a path between indulgence and asceticism. This Middle Way is built on the four noble truths, namely that all life is suffering, that suffering springs from being separated from one's divine source, that craving for the vanities of the material world can be mastered and in doing so one can free oneself from further suffering and that the path to Nirvana is open to all and can be attained through the mastery of the eight disciplines, known collectively as the Eightfold Path (Roland 2000:86).

In contrast with these humanistic worldviews, the biblical approach is God-centred. Tripp (2005:19) speaks of the 'Godward orientation' of the Christian educator (Rm 1:18-19). Learners who have been guided to respond to God in faith find fulfilment in knowing and serving God. Instead of depending solely on the self for becoming a moral agent who is able to respond appropriately to God's universal Moral 
Law, learners depend on external assistance, namely that of a person who can effectively guide them towards fully understanding and committing to a Godward orientation. They depend on a person who can manage the shaping influences of life so that the desired goals for the life of each learner can be realised. Instead of depending solely on the self for reaching such goals, Tripp (2005:25) maintains, the educator must pray that 'God will work in and around [his or her] efforts and the responses of [the] learners to make them people who know and honour God'. This must be done because God is concerned with the heart of the learner, the wellspring of life (Pr 4:23).

Because God is concerned with the heart of the learner, the typically effective teacher should focus less on the learners' external behaviour and rather on the internal state of the heart. They have to be concerned less with the 'what' of their learners' behaviour than with the 'why' thereof - the 'why' being their natural inability to conform to the norms of God's universal Moral Law. Instead of spending most of their time and energy controlling and constraining the behaviour of their learners, they have to concentrate on the state of the latter's hearts. When educating short-circuits to behaviour, says Tripp (2005:xi), educators miss the opportunity of making their learners understand that straying behaviour displays a straying heart - a heart that is not God-centred.

Space does not allow a detailed discussion of teaching and educating from a biblical perspective. Suffice it therefore to say, with Tripp (2005:xix) and Tripp and Tripp (2008:11), that teaching, or educating, is a multifaceted task. It does not only involve a kind authority, a process of shepherding the learners to understand themselves and their places in God's world and a keeping of the gospel in clear view so that the young people can internalise the good news and live in mutuality with other people under God. Educating from this perspective means shepherding the hearts of young people. Instruction of this nature does not only inform the mind. It is directed to persuading the heart of the wisdom and truthfulness of God's ways (Ps 145:4). The truly effective teachers who work with their learners from a biblical perspective will have a sense of the importance of God's words in Deuteronomy:

Take to heart all the words I have solemnly declared to you this day, so that you may command your children to obey carefully all the words of this law. They are not just idle words for you they are your life. (Dt 32:46-47)

\section{Empirical investigation}

To determine whether learners indeed tended to operate with the discrepancy mentioned above, we selected 100 15-year-old learners from each of the following 10 countries: England, Latvia, Greece, Slovenia, Serbia, Bulgaria, Turkey, Pakistan, South Africa and Mexico. We selected these countries on the basis of whether we could find a co-worker prepared to cooperate in this project. The countries that became involved represent a large part of the variety of countries in the world, both geographically and in terms of development continuum.
In each of these countries, we identified a co-worker who was prepared to select the respondents randomly and to request the respondents to write an essay on what a typical teacher would look like in their (the learner's) opinion. They were also encouraged to write about any teacher qualities they could think of, including - but not limited to - such mundane aspects as appearance, clothing, speech and behaviour. We expected the project to provide us with a global picture of the image of teachers (and by extension, the teaching profession) held by learners. With the assistance of the co-workers, the data were interpreted within the (educational and societal) context of each particular country. The data collection was done in keeping with the conventional ethical principles of such research, namely voluntary participation, confidentiality, absence of deception, no compensation for participation and making available the results to all participants (Strydom 2011:115-123). The collected data were processed by means of the content analysis research method. Content analysis could be defined as the detailed and systematic investigation into a particular body of content in order to identify patterns (Leedy \& Ormrod 2013:150). As a research method, it includes both qualitative and quantitative methods (ibid:150). This method is typically used with narratives or forms of human communication such as diaries, books, newspaper articles, films, television, videos (Nieuwenhuis 2010:101) and, in this study, essays of learners. Leedy and Ormrod (2013) outlines the steps of content analysis as follows:

1. The researcher selects the specific material to be studied.

2. The researcher decides which properties should be studied.

3. The properties are divided into small, manageable segments.

4. The material is investigated with respect to the properties and the segments. (pp. 148-149)

According to Sarantakos (1998:286), one of the strong points of content analysis is that it is unobtrusive and does not influence the respondent.

It is furthermore important to note that it is a basic theorem of comparative international research that data pertaining to the education systems of particular countries should always be interpreted within the context of the societal forces (geographic, demographic, social, cultural, economic, political and religious-philosophical) that have shaped that particular education system (Wolhuter 2012:173). The data pertaining to each country were, therefore, interpreted (and presented in the next section) sequentially and not in an integrated manner.

We focused on 15-year-olds because most learners at that age throughout most of the world are still in the general education phase; they have not yet diverged to professional or specialised education programmes. They were also expected to have had significant exposure to teachers, to no longer be influenced by undue deference to authority, to be more realistic and less prone to idealisation and to not yet be predisposed to the rebelliousness towards adults exhibited by adolescents from the age of about 17 years.

The respondents' essays were analysed and the responses grouped into the following five sets of categories: 
1. gender and age

2. clothing, jewellery and accessories

3. tone of voice, voice register, facial expression and body language

4. personality traits pedagogy

5. use of space in the classroom.

\section{Findings England}

The majority of respondents (75\%) described a male teacher and the rest $(25 \%)$ a female teacher. Some of the respondents described a horror character, using words such as 'evil', 'nasty', 'moody' and 'shut up' to characterise a teacher. Others portrayed a person with a more pleasant personality, with descriptions such as 'polite', 'sophisticated', 'smart', 'professional' and 'energetic.' The majority of them agreed that 'a teacher is always conscious of his or her appearance'. They generally thought that teachers were dressed formally. A particular age for the typical teacher was not specified although the writings seemed to describe seniors.

Learners described the facial expressions of teachers that they did not like as 'harsh', 'strict', 'stiff or robot-like' and 'quiet'. Respondents did attach some significance to body language. They believed that the ideal teacher would have confident body language that would grasp and maintain a learner's enthusiasm for the subject.

Very few learners wrote about the tone of voice and the use of space in the classroom. The few who did noted that teachers should be seen by all, and they should make sure that all learners in the classroom understood them. A second strong theme was that the teacher should have a loud voice, clear speech and use English correctly. Respondents viewed the typical teacher as helpful, hardworking, knowledgeable, organised and sociable.

\section{Latvia}

The majority $(79 \%)$ of respondents specifically noted the typical teacher's gender whereas $21 \%$ portrayed a genderneutral teacher. Most respondents (59\%) described the typical teacher as a woman whereas $6 \%$ of respondents described the typical teacher as a man and $6 \%$ described the typical teacher as both male and female. The majority of respondents (71\%) did not identify age. The written descriptions revealed that the teacher was middle-aged - no descriptions of very young or very old teachers appeared.

Respondents mentioned descriptors of clothing such as 'appropriate', 'acceptable', 'neat', 'respectable' and 'practical'. Analysis of responses indicated that teachers were modest in terms of wearing jewellery and accessories. Regarding facial expression and body language, only $6 \%$ of respondents noted that the teacher often smiled. Respondents valued emotions, both verbal and in behaviour, as negative. Typical teachers hold a pen, pointer or bag in their hands and speak accurately and correctly in a loud, clear voice. They either stand or sit in front of the class, gesticulating, and are angry, pre-occupied and in a hurry.

\section{Greece}

Respondents' descriptions of teachers were almost equally divided between young and middle-aged. The most frequent response relating to clothing and accessories was a casual and modern look (67\% of responses): jeans, T-shirts and pullovers. This supports the image of the teacher as somebody of young age. Regarding the tone of voice, they also seemed to describe a young teacher. Descriptions such as 'serious', 'gentle', 'calm' and 'friendly' were the most commonly used words to depict the typical teacher. The teacher's facial expressions and body language were also portrayed as serious, though happy and smiling, with a sense of humour and coupled with many gesticulations. Some learners indeed mentioned that strict, serious and 'old and tired teachers' negatively influenced the classroom and teacher-pupil relations.

Regarding the use of space in the classroom, respondents saw the teacher in a classical situation: standing with a pen or pencil in front of the blackboard or sitting at a computer desk. They also included descriptions related to personality and professionalism in their answers on the visual image of teachers: 'I would like my teacher to be a sensitive and nice person', 'imagination is of great importance for a modern teacher' and 'if my teacher is objective and collaborative, I feel good, this is the real democracy of the classroom.' They indicated that the ideal teacher should be a person who cares about learners, whose behaviour is democratic and friendly, who favours collaboration, who uses imagination in class and who is someone that 'should be very well educated'. The ideal teacher is someone who tries to encourage learners to love school and lessons.

\section{Slovenia}

Only $46 \%$ of the respondents described the typical teacher as a woman whilst $4 \%$ of respondents described him as a man, and $4.5 \%$ described the teachers as either man or woman. The rest $(45.5 \%)$ made no reference to gender. Concerning the age of the typical teacher, the responses ranged from young to middle-aged.

Concerning clothing, jewellery and accessories, the analysis of responses revealed two predominant images. The first image was of a younger teacher wearing nice, comfortable, casual, fashionable clothes, usually jeans and T-shirts. The second image was of an older teacher wearing 'classical', 'oldfashioned' clothes.

The majority of the respondents said that a typical teacher spoke loudly and clearly. Some elaborated upon this in a negative way ('too loud', 'annoying voice') and others in a more positive way ('she has a nice, sweet and relaxed manner of speaking').

A recurring theme amongst the respondents was that a typical teacher spent most of the time standing in front of the 
classroom explaining the learning matter. Personality traits also seemed to be important to respondents. Two dissimilar, yet equally pronounced, images of the typical teacher transpired. One was a strict and demanding, yet also patient, just and encouraging teacher. The other was the image of a strict, rude, bossy, nagging teacher, who is not ready to help.

\section{Serbia}

About half of the respondents described the teacher as a woman, and some combined male and female descriptions. Half of the respondents who addressed the issue of age opted for a 'young' teacher, 33\% for a middle-aged (or in his or her forties) teacher and only $16 \%$ for an elderly person.

Almost all of the learners paid attention to the teacher's clothing. The dominant image that transpired was of a fairly casually, yet decently, dressed teacher. Trousers, jeans, shirts, T-shirts, pullovers and shoes or sneakers were most often mentioned. Half of the learners mentioned jewellery and accessories. The teacher would use jewellery, accessories and cosmetics discreetly.

It was apparent that learners considered the teacher's tone of voice an important feature of behaviour. Most had a positive appreciation of the teacher's voice, describing the teacher's speech as clear, articulate and even loud. The teacher's tone of voice was also sporadically described as irritating, piercing, shouting or ugly.

Learners' descriptions of a typical teacher's facial expressions and body language were rather divided. Some of them perceived the teacher as calm, even-tempered, smiling and kind. Others opted for terms such as strict, frowning, angry, nervous, constantly tired and with a 'wrinkled' forehead.

The use of space in the classroom is an element to which learners paid little attention - responses were either absent or very short. In the experience of some learners, the typical teacher walked around in the classroom whilst teaching or observing what and how the learners performed. Other learners perceived a typical teacher as mostly standing in front of a blackboard or seated at the teacher's desk.

\section{Bulgaria}

Most respondents described the typical teacher as a middleaged female. Most of the respondents stated that the typical teacher wore casual clothes. Younger teachers predominantly wore jeans and blouses. The most typical accessories worn by teachers were scarves, earrings, rings, bracelets and various pendants. Only one noted that tattoos were an acceptable decoration for younger teachers but only if they were discreet and pretty.

The typical teacher's voice was described by $73 \%$ of learners as low, deep and authoritative but nevertheless energetic; they thought that some teachers' voices were just the opposite: high-pitched, monotonously slow, demanding and dominant, and sometimes melancholic. The facial expression of the typical teacher was described as calm, jovial, friendly and sympathetic whilst $25 \%$ of respondents thought that it was angry, frustrated or vicious, contemptuous and ironic. Most respondents described the facial expressions and gestures of the typical Bulgarian teacher as calm, open and co-operative.

The majority of respondents commented that the typical teacher was usually dynamic in the classroom: either standing or walking between the desks and sometimes sitting amongst the learners but always interacting with learners, checking homework or teaching new material. In contrast, $15 \%$ of respondents indicated the opposite: that the typical teacher was mainly static, standing in front of the learners, sitting at the desk or just walking back and forth at the board.

\section{Turkey}

An analysis of responses indicated that learners perceived teaching as a female-dominated profession. Respondents described the typical teacher as 'clean', 'neat' and 'tidy', a 'modest' female with 'little makeup' - an example to be followed and respected.

Regarding the teacher's speech and tone of voice, responses indicated that the typical teacher was someone whose voice was 'loving' and 'kind'. One of the respondents suggested that the typical teacher 'speaks as sweetly as a woman singing to her flowers'. Some respondents indicated that a teacher 'very rarely shouts'.

Regarding the teacher's character, personality and professional traits, learners characterised a typical teacher as 'good-hearted', 'loving', 'kind', 'friendly' and 'good-natured'. Learners also described a teacher as 'tolerant' and 'patient'. The teacher should be 'knowledgeable', 'a learner', 'competent', 'disciplined' and 'in control of the class'. Some respondents described the teacher as 'someone who does not threaten learners with low grades, someone who is fair, and someone who masters the balance between authority and friendship'.

\section{Pakistan}

The sample consisted of 50 boys from boys' schools and 50 girls form girls' schools. For the boys, the ideal teacher was male, and for the girls, the ideal teacher was female. There was an assumption amongst girls that female teachers were either unmarried or, if married, childless. When it came to age, respondents described the ideal teacher using the term 'young'. None of the learners described an old teacher.

Regarding clothing and accessories, boys most frequently mentioned the traditional Pakistani shalwar kameez [a traditional dress worn by both women and men in South Asia and Central Asia]. Only one respondent mentioned a formal shirt and tie. Most of the respondents saw the typical teacher as neat, decent, simple and economically clothed. Girls preferred the teacher to wear a dupatta [Pakistani scarf]. Wristwatches were mentioned by most of the respondents. 
A loud, clear voice was regarded as an indispensable feature of the ideal teacher since it indicated someone who was in control and who was able to maintain discipline in the classroom. Others described the teacher's tone of voice as irritating and ugly: 'He or she shouts most of the time during lessons to control the learners.' Learners stated that a teacher's body language and facial expressions were critical in successful classroom settings. In general, learners felt that, if teachers were 'calm', 'soft', 'pleasant' and 'open', their learners responded more positively than did the learners of teachers who demonstrated closed and defensive body language.

With regard to the use of space, respondents described the typical teacher as teaching from the front of the classroom. Some referred to a certain style of teacher movement such as walking around the classroom, holding a stick to scare learners or standing behind a chair.

\section{South Africa}

In their portrayals of teachers, $45 \%$ of the respondents noted a woman, $20 \%$ noted a male, $20 \%$ referred to both male and female, and $15 \%$ made no reference to gender. Two respondents stated that the typical teacher could only be a woman and explained that the statement was based on their experience and perception of male teachers as being intoxicated during school hours or entering into improper relations with female learners. Regarding clothing, a prevalent theme was that the teacher should dress formally, professionally, decently and neatly. Clothing gives authority, as does a strong voice. Respondents believed that the teacher should speak in a loud and clear voice so that everyone, even those sitting at the back of the class, could hear.

Respondents wrote more about the teacher's use of space in the classroom and teaching style than about any of the other categories. A recurring theme was that the typical teacher made sure that all learners understood and followed. Many wrote that the teacher would walk around in the class in order to make sure that even the learners at the back of the classroom could understand. The typical teacher should respect all the students and would be a mother or father figure, empathetic, helpful and somebody one could talk to. The few who described their encounters with teachers complained about poor relationships. They also noted substance and alcohol abuse by teachers, sleeping in class and talking on mobile phones during class.

\section{Mexico}

The responses here indicated that, for the majority of learners, women were representative of the teaching profession. Teachers' clothing corresponded with their age: older teachers dressed more elegantly and formally and had a good appearance. Words such as 'neat', 'clean' and 'careful' were often used to describe attire.

The majority (90\%) of the respondents indicated that their teachers' voices were loud. Some commented that this was so that the whole group could hear the lesson. A third of the learners said that their teachers' voices caused them to feel rejected, and another 33\% reported that they felt that their teachers were authoritarian.

Regarding the personality and behaviour of teachers, half of the respondents said that their teachers were well-mannered and that they liked the way in which their teachers worked. Also, they had good communication skills and were able to make classes a lot of fun.

Regarding body language, respondents reported that some teachers were expressive and made them feel confident. The movement of their bodies and the way they approached a student either evoked security or fear. One pupil wrote: 'My teacher is weird, when she approaches me, it is scary.'

Regarding the use of space in the classroom, learners depicted a range of situations. Some depicted the teacher at the black board explaining something in front of the class whilst others described a teacher standing by the learners to clarify their understanding.

\section{Discussion}

Firstly, the study on the image of the teacher held by learners produced three narratives: the bad teacher, the ideal teacher and the good teacher. The bad teacher seems typically to be a person with a number of less-acceptable dispositions. Because no consistent pattern emerged from all the sets of responses, it seems unnecessary to further expand on the notion of the 'bad' teacher. Suffice it to mention that teachers should take cognisance of those characteristics, mannerisms and behaviours that seem to irritate their students and do their utmost to avoid such conduct.

Secondly, the findings seem inconclusive about the characteristics of the ideal teacher in the sense that some respondents (from a particular country) would lay strong emphasis on one feature, attribute or characteristic whilst others would emphasise quite a different set of attributes. This seems to confirm the impression from the literature that, to date, no final and conclusive set of features, attributes or characteristics of the ideal or totally effective teacher could be defined.

Thirdly, whilst the catalogue of positive traits and behaviours of a 'good' teacher that emerged from this investigation seems realistic and reasonable, it would be difficult to find all these attributes and behaviours concentrated in one specific individual. No single person can constantly:

- have a pleasant personality

- be conscious of own outward appearance

- be confident about own body language

- be well understood by all, particularly the students

- speak clearly, with a melodious voice, audible even in the furthest corners of a classroom

- use a pleasant tone of voice 
- avoid becoming angry or agitated

- be hardworking, empathetic, sociable, friendly, strict, demanding yet patient, just and encouraging, tolerant, patient, good-hearted and disciplined

- maintain good class discipline

- be in control of things

- maintain good relationships with everyone

- be calm, open and cooperative.

Neither can the same person always be fully professional and present in class, well educated, knowledgeable, competent, able to engage with every student and always dynamic.

This catalogue of attributes typically describes what we termed the ideal-type teacher and the totally effective teacher. These two images, as we argued, do not exist in real life. Fortunately, if we assess the responses of the learners from the 10 countries that we mentioned, we find that they also provided for real-life flesh-and-blood people: people who will not always and consistently behave like super-human educators but who are actual people, inspired about their profession and enthusiastic about their respective subjects. It was expected that the learner respondents in the 10 countries would come from widely diverse cultural, religious and worldview backgrounds. Therefore, we did not concentrate on the impact that the respective cultural, religious and/or worldview assumptions may have had on the respondents' views about the ideal or typical teacher. We rather, as explained above, concentrated on how they experienced the teachers as they (the teachers) actually operated in the respective classrooms. Since this particular study ${ }^{1}$ did not enter into the problem of the particular worldview which would have driven or inspired the teachers to be effective or 'good', it would not be scientifically justifiable to enter into a detailed discussion of what the teachers should have done to lead their learners to conform to the universal Moral Law of God, as discussed above. For all we know, some teachers are already guiding their learners to conform to this law.

Suffice it to say, therefore, that as authors of this article, we would have preferred all teachers to:

- Guide, equip, lead and enable (i.e. shepherd) their learners to perform according to the creation mandate.

- Be well prepared for their life calling of loving themselves, their neighbour and, above all, the triune God of the Bible as well as for their calling to execute loving and caring stewardship of the entire creation to the glory of God.

- Make disciples of their learners in the sense of inspiring them to emulate the examples of their teachers.

In disciplining them, we would expect the typical effective teacher to concentrate less on external discipline than on the Godward-oriented discipline of the hearts of the learners.

Fourthly, the responses show that neither gender nor age plays a conclusive role in what learners regard to be a typical teacher.

1.Another study is already underway in which the impact of teachers' respective worldviews on their work in classrooms could be assessed.
Fifthly, it was always thought that the teachers' place in the classroom is at the front of the class where they can be seen by all. This was confirmed as late as the 1990s, based on research conducted in 1000 American schools (Weber \& Mitchell 1998:28). The research reported in this article indicates a positive development, though. The teacher has become more dynamic and moves around the room. The teacher tends to walk between the rows, gesticulates, sits amongst the learners and works with individual learner groups. In harmony with this change is the change in clothing choice, namely 'comfortable', as discussed. Teachers wear clothing that allows them freedom of movement.

Sixthly, the voice, attire, body language and general conduct of the teacher affects learning and the maintenance of discipline. All of these butt into the keystone, namely the assumption that the teacher should be a role model for learners. Unfortunately, as the responses from South Africa in particular show, learners are occasionally expected to interact with teachers who are no role models.

\section{Conclusion}

This study has once again demonstrated the unity of humankind the world over. Although the responses were tinged by the local circumstances prevailing in the learners' own respective countries and in their respective systems of education, it was possible to draft a catalogue of teacher attributes and behaviours that would find universal approval amongst students. It is true that this catalogue seems to depict a person who might never exist and therefore rather belongs to Plato's ideal world or to Kant's noumenal world. However, it would be worthwhile for practising teachers as well as those currently in pre-service teacher education not only to take cognisance of these attributes but also to try and master as many of them as possible since that might contribute to the discipline in their classes. Whilst no single teacher will ever - as far as can be foreseen for now - embody all of the desired attributes, the mastery of as many of them as possible will help a teacher to become what we termed the typically excellent teacher. The important role that the teacher as transformative, spiritual agent - an aspect of being a teacher that the respondents in this study largely left by the wayside - may play in this regard should be investigated in subsequent studies.

\section{Acknowledgements Competing interest}

The authors declare that they have no financial or personal relationship(s) that may have inappropriately influenced them in writing this article.

\section{Authors' contributions}

All authors C.C.W. (North-West University), J.L.v.d.W. (North-West University) and F.L.P. (North-West University) contributed equally to the writing of this article. 


\section{References}

Beishuizen, J.J., Hof, E., Van Putten, C.M., Bouwmeester, S. \& Asscher, J.J., 2001 'Students' and teachers' cognitions about good teachers', British Journal of Educational Psychology 71, 185-201. http://dx.doi.org/10.1348/000709901158451, PMid:11449932

Cilliers, S., 2009, 'Slagoffer van skoolaanval nou tuis onderrig', Beeld, 02 April, bl. 4. Cloud, H. \& Townsend, J., 1992, Boundaries, Zondervan, Grand Rapids.

Collins, J.R., 2009, 'Redeeming the enlightenment: New histories of religious toleration' The Journal of Modern History 81(3), 607-636. http://dx.doi.org/10.1086/599275

Cothran, D.J. \& Hodges Kulinna, P., 2006, 'Students' perspectives on direct, peer, and inquiry teaching strategies', Journal of Teaching in Physical Education 25, 166-181.

De Muynck, B., 2008, 'Summary of the dissertation “A Godly Vocation"', paper presented at the Conference on Spirituality in Education, Driestar Educatief (Pedagogical University), Gouda, Netherlands, January 2008.

Dennett, D., 2003, Freedom evolves, Viking Press, New York. PMCid:PMC194910

Department of Education and Science and the Welsh Office (DESWO) (United Kingdom), 1989, Discipline in schools: Report of the Committee of inquiry chaired by Lord Elton, Her Majesty's Stationery Office (HMSO), London.

De Wet, C., 2010, 'School principals' experiences and observations of educator-targeted bullying', Journal for Christian Scholarship 46(1), 187-209.

Dyer, J., 2002, 'Characteristics and behaviours of effective social education teachers', Ethos P-6 10(3), 8-10.

Eloff, C.H., Oosthuizen, I.J. \& Steyn, H.S., 2010, 'An educator approach towards learner discipline as a prerequisite in dealing with learner misconduct', Journal for Christian Scholarship 46(1), 125-144.

Engebretson, K., 2003, 'Young people, culture and spirituality: Some implications for the ministry', Religious Education 98(1), 5-24. http://dx.doi.org/10.1080/ 00344080308297

Freire, P., 2007, Pedagogy of the oppressed, Continuum, New York/London.

Hardjono, T. \& Klamer, H., 2005, Breng spirit in je werk!, Uitgeverij Meinema, Zoetermeer.

Heystek, J., 2010, 'Onderwyser-leierskap vir positiewe onderrig- en leerklimaat [Teacher leadership for positive teaching and learning environment]', Tydskrif vir Christelike Wetenskap 46(1), 39-53.

Korthagen, F. \& Vasalos, A., 2005, 'Levels in reflection: Core reflection as a means to enhance professional growth', Teachers and Teaching 11(1), 47-71. http://dx.doi. org/10.1080/1354060042000337093

Leedy, P.D. \& Ormrod, J.E., 2013, Practical research: Planning and design, Pearson Education, Upper Saddle River.

Liu, S. \& Meng, L., 2009, 'Perceptions of teachers, students and parents of the characteristics of good teachers: A cross-cultural comparison of China and the United States', Educational Assessment, Evaluation and Accountability 21(4), 313-328. http://dx.doi.org/10.1007/s11092-009-9077-z

Millei, Z., Griffiths, T.G. \& Parkes, R.J., 2010, Re-theorizing discipline in education Problems, politics and possibilities, Peter Lang, New York.
Moore, A., 2004, The good teacher: Dominant discourses in teacher education, Routledge Falmer, New York. http://dx.doi.org/10.4324/9780203420270

Nieuwenhuis, F.J., 2010, 'Analysing qualitative data', in K. Maree (ed.), First steps in research, pp. 99-123, Van Schaik, Pretoria.

Nussbaum, M.C., 2000, Women and human development: The capabilities approach, Cambridge University Press, Cambridge. http://dx.doi.org/10.1017/CBO97805 11841286

Pinto, L.E., Portelli, J.P., Rottmann, C., Pashby, K., Barrett, S.E. \& Mujawamariya, D., 2012, 'Charismatic, competent or transformative? Ontario school administrators' perceptions of "good teachers", Journal of Teaching and Learning 8(1), 73-90.

Robeyns, I., 2005, 'The capability approach: A theoretical survey', Journal of Human Development and Capabilities 6(1), 93-117.

Roland, P., 2000, New Age living: A guide to principles, practices and beliefs, Octopus Publishing Group, London.

Russo, C.J. \& Wolhuter, C.C., (in press), ‘Dealing with incidences of serious learner discipline problems in South African schools: Guidelines from international-comparative perspectives', Koers - Bulletin for Christian Scholarship.

Sarantakos, S., 1998, Social research, MacMillan, South Yawa. profession', in A.S. de Vos, H. Strydom, C.B. Fouché \& C.S.L Delport (eds.), Research at grass roots for the social sciences and human service professions, pp. 113-130, Van Schaik, Pretoria.

Tripp, T., 2005, Shepherding a child's heart, Shepherd Press, Wapwallopen, PA.

Tripp, T. \& Tripp, M., 2008, Instructing a child's heart, Shepherd Press, Wapwallopen, PA. Van Crombrugge, H., 2006, Denken over opvoeding, Garant, Antwerpen.

Van Deventer, I., 2010, 'Education and Social Justice: “Chapter 2: The nature of social justice"', preliminary literature study for PhD thesis, School for Continuing Teache Education, North-West University.

Van der Walt, J.L., Potgieter, F.J. \& Wolhuter, C.C., 2009, 'Addressing the discipline problem in South African schools by increasing the supply of social capital in society: A position paper', Journal of Educational Studies 8(1), 47-59.

Van der Westhuizen, P.C., Oosthuizen, I.J. \& Wolhuter, C.C., 2008, 'The relationship between an effective organizational culture and student discipline in a boarding school', Education and Urban Society 40(2), 205-225. http://dx.doi.org/10.1177/ 0013124507303992

Weber, S. \& Mitchell, C., 1998, 'That's funny, you don't look like a teacher': Interrogating images and identity in popular culture, Falmer Press, London/Washington, DC.

Wolhuter, C.C., 2012, 'Godsdiens in onderwys in Suid-Afrika: Beligting vanuit internasionaal-vergelykende perspektiewe [Religion in education in South Africa: Enlightenment from internationally comparative perspectives]', Tydskrif vir Christelike Wetenskap 48(1/2), 171-201.

Wolhuter, C.C. \& Van Staden, J.G., 2009, 'Gender differences in South African educators' experience and handling of learner discipline problems at school', Journal of Educational Studies 8(1), 100-110.

Wolhuter, C.C., Oosthuizen, I.J. \& Van Staden, J.G., 2010, 'Skoolfase/leerderouderdom as faktor in leerderdissipline in Suid-Afrikaanse skole [School phase/student age as a factor in student discipline in South African schools]', Tydskrif vir Christelike Wetenskap 46(1), 169-186. 